\title{
Qualitative evaluation of school meal menus offered in Brazilian municipalities
}

\author{
Avaliação qualitativa de cardápios escolares oferecidos \\ em municípios brasileiros
}

Rafaella Guimarães Moraes Camargo (https://orcid.org/0000-0002-9668-8713) ${ }^{1}$ Simone dos Anjos Caivano (https://orcid.org/0000-0002-3035-9888) ${ }^{2}$

Semíramis Martins Álvares Domene (https://orcid.org/0000-0003-3003-2153) ${ }^{3}$
${ }^{1}$ Programa de PósGraduação Interdisciplinar em Ciências da Saúde, Universidade Federal de São Paulo. Rua Silva Jardim 136, Edifício Central. 11015-020 Santos SP Brasil. raguimanutri@gmail.com

${ }^{2}$ Laboratório de Dietética Experimental, Universidade Federal de São Paulo Federal. Santos SP Brasil. ${ }^{3}$ Departamento de Políticas Públicas e Saúde Coletiva, Instituto Saúde e Sociedade, Universidade Federal de São Paulo. São Paulo SP Brasil.

\begin{abstract}
This article aims to evaluate the quality of Brazilian school meal menus. Cross-sectional study that analyzed 2,500 menus of 500 Brazilian municipalities. The menus were evaluated based on the Quality Index for School Meal Menus (IQCAE - Indicador de Qualidade para Cardápios da Alimentação Escolar). The data were submitted to descriptive analysis. We found that $29,4 \%$ of menus presented high quality; 50,6\%, regular quality; and 20\%, low quality. Grains and tubers (86\%) and Meat and eggs (67\%) were the groups most found in menus, followed by Legumes (42,16\%), Vegetables (40\%), Fruits (35,56\%), and Dairy products (18,6\%); the frequency of Cured meats and sausages $(8,68 \%)$ and Sweets as meals (3,64\%) was lower. Among other components, $84,6 \%$ of the menus offered Sweets as dessert in none or one day a week; ultra-processed foods appear in $65,6 \%$ of menus at least once a week. In $22 \%$ of the menus, meal time was compatible with type meal served. Important food for child nutrition, such as dairy, vegetables, and fruits, are not regularly provided by school meals. Despite the advances in policy management, the presence of ultra-processed foods at least once a week is still frequent in the menus.
\end{abstract}

Key words School feeding, Menu planning, Quality index
Resumo O objetivo deste artigo é avaliar a qualidade de cardápios escolares brasileiros. Estudo transversal analisou 2.500 cardápios, de 500 municípios brasileiros, com base no Indicador de Qualidade para Cardápios da Alimentação Escolar. Os dados foram submetidos à análise descritiva. Observou-se que $29,4 \%$ dos cardápios apresentaram alta qualidade, 50,6\% qualidade regular e $20 \%$ baixa qualidade. Cereais e tubérculos (86\%) e carnes e ovos (67\%) foram os grupos de maior frequência nos cardápios, seguidos de leguminosas (42,16\%), hortaliças (40\%), frutas $(35,56 \%) e$ laticínios (18,6\%); a frequência da oferta de alimentos embutidos (8,68\%) e doces como refeições $(3,64 \%)$ foi menor. Entre os demais componentes, $84,6 \%$ dos cardápios ofertavam doces como sobremesa em nenhum ou em apenas um dia da semana; os formulados aparecem em 65,6\% dos cardápios pelo menos uma vez por semana. Em $22 \%$ dos cardápios o horário estava compatível com o tipo de refeição servida. Alimentos importantes para a nutrição infantil, como laticínios, hortaliças e frutas, não são oferecidos regulamente na alimentação escolar. A despeito dos avanços observados na gestão da política, a presença de formulados pelo menos uma vez por semana ainda é frequente nos cardápios.

Palavras-chave Alimentação escolar, Planejamento de cardápio, Indicador de qualidade 


\section{Introduction}

The monitoring of the quality of school meal menus can be understood as a Food and Nutritional Security strategy when considering the school an environment that promotes healthy habits ${ }^{1}$, built from positive food experiences and by food education activities ${ }^{2}$.

The National School Feeding Program (PNAE - Programa Nacional de Alimentação Escolar) is the largest and oldest food and nutrition program in Brazil, and meets about 50 million people, who receive at least one meal a day ${ }^{3}$.

Since 1994, the management of school meals has been decentralized to states and municipalities, which enables the provision of a quality meal by concentrating funds in the cities, thus encouraging the acquisition from local producers, with fresher and regional foods ${ }^{1,4}$. Throughout the course of PNAE, it was possible to note episodes that directly or indirectly affected the quality of the meals served; the legal milestones of the Program are Law no. 11,947 of 2009 and National Education Development Fund (FNDE) Resolution no. 26 of 2013, which provided a legal basis for the establishment of the implementation parameters of the Program and for menu planning. These parameters also allow us to evaluate menus in a larger perspective, which complements the provision adequacy of energy and nutrients ${ }^{5}$.

However, nationwide studies on the nutritional quality of school meal menus are rare in the literature. Brazil has few and located research in this field; studies using the method Qualitative Evaluation of Menu Meals are available in three municipalities ${ }^{6-9}$; in Santa Catarina, the Qualitative Evaluation of School Meal Menu was used in a statewide study ${ }^{10}$; in Rio de Janeiro, the Evaluation of Nutritional and Sensory Quality was used to evaluate protein meals in two schools ${ }^{11}$; and, in Belo Horizonte, an analysis by direct weighing of food was conducted in 42 schools $^{12}$. In addition to these findings, studies on the compliance with Resolution no. 38 of 2009 , conducted in two capitals $^{13}$, and on the presence of regional preparations, nationwide ${ }^{14}$, are also available.

Given the magnitude and coverage of PNAE, this study aims to evaluate the quality of the menus served in Brazilian municipalities, which competed for the Efficient Manager of School Feeding Award (PGEME) in 2011.

\section{Methods}

\section{Study and sample design}

This is a cross-sectional study with secondary data from 2,550 weekly menus of 510 municipalities, which took part in PGEME in its 2011 edition. All menus with complete data offered to schoolchildren, from Monday to Friday, were part of the study. Exclusion criteria were: lack of information on at least one day of the week; menus offered in feast days; and menus with filling inconsistency. Data on the municipality, sociodemographic aspects, and weekly menus (name of the preparation and description of the ingredients used for the meal) were used in the research.

\section{Quality evaluation of the menus}

The menus were analyzed by the application of the Quality Index for School Meal Menus ${ }^{4}$, instrument validated by Camargo ${ }^{15}$ that considers the weekly or daily occurrence of each of the components. For the score of the components, the foods included in the menu description were considered. This method proposes the global evaluation of the menu in one week, considering its meals according to the following criteria:

a) daily supply components: grains and tubers; legumes; vegetables; fruit; meat and eggs; dairy products; sweets in place of meal; cured meats and sausages; compatibility of time with meal type offered.

b) weekly frequency components: sweets as dessert; ultra-processed foods; and if other food was offered.

The spreadsheet with the algorithm and guide for the application of IQCAE is available and can be sent by the main author via email.

\section{Data processing}

The data typed in the Excel spreadsheet were verified to analyze the consistency of the information. Qualitative predictor variables were transformed into dummy variables: the occurrence of foods in the components of IQCAE was registered in the categories "presence" (1) and "absence" (0) to compose the score.

The evaluation of menus with the application of IQCAE can reach the maximum score of 5,4 points in the week and 1,04 per day. The classification of menus considers the occurrence of food that represent quality or health risk, according to the following criteria: 
- From 0 up to 1,80 points: low-quality menus

Menus that are not regular regarding the type of meal in the different days of the week (sometimes lunch-type meals, sometimes snack-type meals) and that mostly contain foods that bring risk to health (above two occurrences in a week);

- 1,81 to 3,00 points: intermediate quality menus

Menus that may present markers of healthy nutrition and, occasionally, health risks (up to two occurrences in a week);

- Above 3,00 points: high-quality menus

Menus that do not contain food that represent risk, such as cured meats and sausages, candies, and ultra-processed foods.

\section{Data analysis}

The database was rendered by the software Statistical Package for Social Sciences (SPSS 18). Descriptive analyses were undertaken of the variables with mean values, standard deviations, and frequency of the weekly and daily evaluation components of IQCAE. Kolmogorov-Smirnov normality test was applied to run the statistical tools and interpret the results from IQCAE, and chi-squared test was used to analyze the categorical variables. ANOVA and Tukey's post hoc test were used to compare means between the Brazilian regions. A 0.05 significance level was adopted to analyze the variables.

\section{Ethical aspects}

This study was approved by the Research Ethics Committee of the Federal University of São Paulo.

\section{Results}

2500 daily menus were evaluated, generating 500 weekly menus registered in the database for 500 Brazilian municipalities. The greatest contribution of menus corresponds to the Southeast region $(40 \%)$; followed by the South $(27,8 \%)$; Northeast (18,6\%); Midwest (7,6\%), and North $(6 \%)$.

We verified the frequency of weekly and daily evaluation components and the percentage of menus regarding quality and Brazilian region studied (Table 1).

\section{Daily evaluation components}

The group that presented the highest frequency was Grains and tubers (86\%), followed by Meat and eggs (67\%), Legumes (42,16\%), Vegetables $(40 \%)$, Fruits $(35,56 \%)$, Dairy products (18,6\%), Cured meats and sausages $(8,68 \%)$, and Sweets in place of meal $(3,64 \%)$. The meal time was compatible with meal type in in $21,84 \%$ of the sample (Graph 1).

\section{Weekly evaluation components}

Four $(0,8 \%)$ out of the 500 weekly analyzed menus presented sweets as dessert 4 or 5 times a week; $14,60 \%$, from to 2 to 3 times; and $84,60 \%$, up to 1 time. In turn, the provision of ultra-processed foods was more frequent: only $34,4 \%$ of the menus did not have this component; of the remaining $65,6 \%, 25,6 \%$ offered them 1 time a week; $25,6 \%, 2$ or 3 times; and $14,4 \%, 4$ or 5 times a week.

\section{Menu classification}

The score of the menus generated values between 0,28 and 4,4, with the following result: low-quality menus $(\mathrm{n}=48)$; intermediate-quality menus $(n=252)$; high-quality menus $(n=100)$. Table 1 contains the quality of the menus according to Brazilian region.

\section{Discussion}

The evaluation of food and nutrition policies and programs is one of the main challenges for public management, and it can provide parameters to set priorities in health and nutrition concerning resource allocation and intersectoral actions. There is no published nationwide study evaluating the quality of school meal menus, despite the importance and scope of PNAE, which meets 50 million Brazilians in 200 days of the year and moved, in 2015, about 3,8 billion reals ${ }^{3}$.

Regarding menu planning, the nutritionists of school meals have at their disposal standards provided by the Brazilian law, and the adoption of these parameters contributes to ensure a safe, adequate, and quality nutrition. Another important guiding instrument for nutritionists is the Food Guide for the Brazilian Population (GAPB, 2014), which has the incentive to the consumption of foods with a low degree of processing as a fundamental guideline ${ }^{18}$. 
Table 1. Distribution of school meal menus according to quality and Brazilian region. Brazil, 2019.

\begin{tabular}{|c|c|c|c|c|c|c|c|c|c|c|c|c|}
\hline \multirow{3}{*}{ Menu quality } & \multicolumn{12}{|c|}{ Region } \\
\hline & \multicolumn{2}{|c|}{ Midwest } & \multicolumn{2}{|c|}{ Northeast } & \multicolumn{2}{|c|}{ North } & \multicolumn{2}{|c|}{ Southeast } & \multicolumn{2}{|c|}{ South } & \multicolumn{2}{|c|}{ Total } \\
\hline & n & $\%$ & $\mathbf{N}$ & $\%$ & $\mathrm{n}$ & $\%$ & $\mathbf{N}$ & $\%$ & $\mathbf{n}$ & $\%$ & $\mathbf{n}$ & $\%$ \\
\hline High & 8 & 8,0 & 12 & 12,0 & 4 & 4,0 & 65 & 65,0 & 11 & 11,0 & 100 & 100,0 \\
\hline Intermediate & 23 & 9,1 & 48 & 19,0 & 14 & 5,5 & 97 & 38,3 & 70 & 28,1 & 252 & 100,0 \\
\hline Low & 7 & 4,7 & 33 & 22,3 & 12 & 8,1 & 38 & 25,7 & 58 & 39,2 & 148 & 100,0 \\
\hline Total & 38 & 7,6 & 93 & 18,6 & 30 & 6 & 200 & 80 & 139 & 27,8 & 500 & 100 \\
\hline
\end{tabular}

Source: Efficient Manager of School Feeding Award (PGEME), 2011.

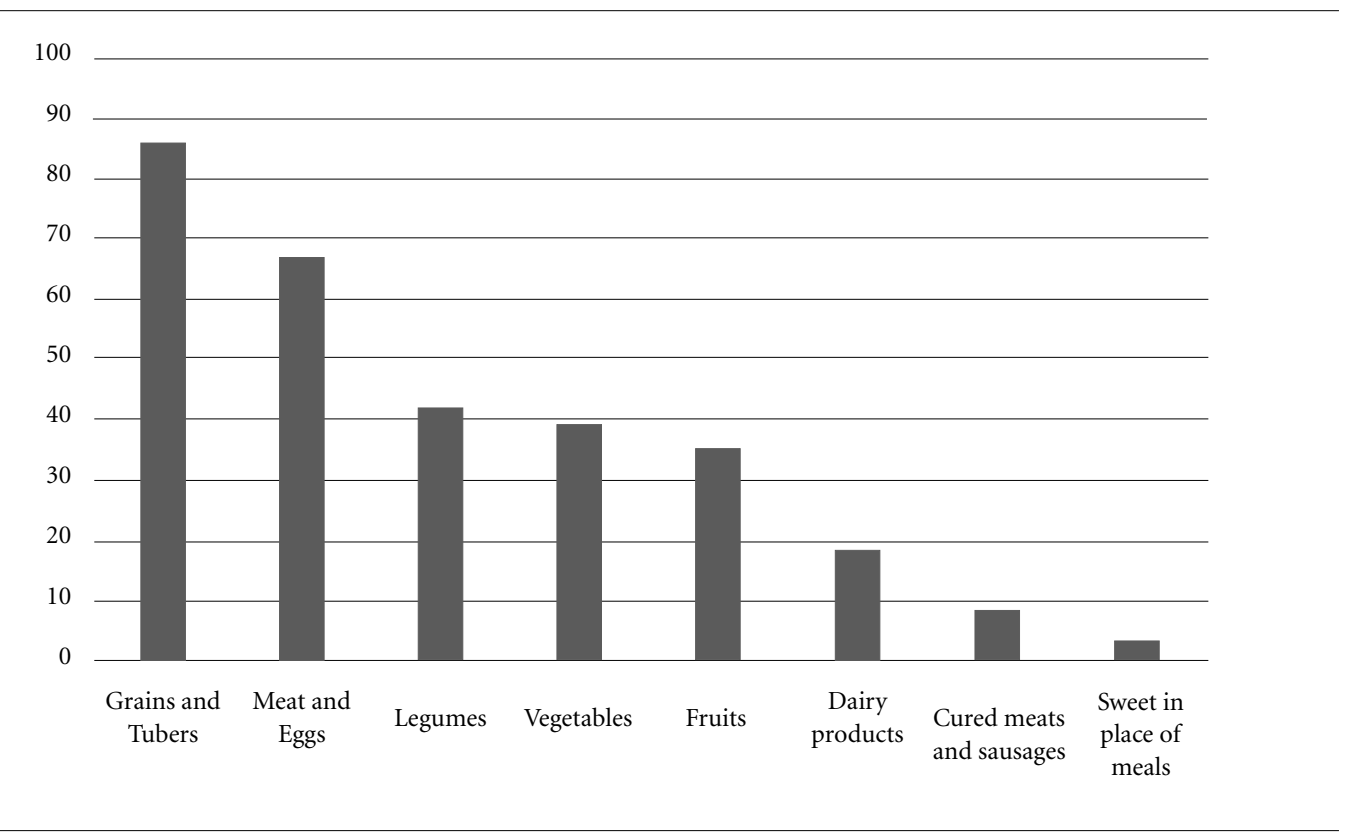

Graph 1. Frequency of daily occurrence of food groups in school meal menus. Brazil, 2019.

Source: Efficient Manager of School Feeding Award (PGEME), 2011.

IQCAE allows one to carry out an overall evaluation of the menu; the guide serves helps one apply IQCAE, but may be questioned regarding the categorization of food groups. For example: fruit candies are categorized as candy according to FNDE technical note ${ }^{23}$. Another example occurs with tomato sauce (industrialized or natural) that is categorized in the vegetable group; this takes place by the amount of sauce used in the preparation. Regarding the degree of processing, according to the GAPB, tomato sauce can be categorized as processed food ${ }^{18}$; however, IQCAE does not have an intermediate category between fresh foods and ultra-processed foods by the fact that restricted and prohibited foods in PNAE are all ultra-processed.

The qualitative analysis showed a low provision of fruits and vegetables in a week for most menus analyzed, which is at odds with PNAE (at least three weekly portions of fruits and vegetables a week $)^{2}$; although the resolution in force at the time of data collection was different, this parameter was already established. These data confirm the findings of other researchers ${ }^{8-10,13}$, who also found a provision of fruits and vegetables less than three times a week. These food groups are responsible for providing micronutrients and bioactive compounds that contribute to prevent a double bur- 
den of diseases and to the appropriation process of healthy food choices at this life stage ${ }^{16}$.

Foods with low nutritional value have restricted use under the law regulating the Program; their purchase is limited to $30 \%$ of federal funds that is transferred to the municipalities ${ }^{2}$. This data, however, were not object of analysis in this study. In spite of this, the provision of sweets in place of meal and sweets as dessert was low, which contributes to the higher quality of the menus; this reality differs from the findings of Vidal et al., which showed, in $90 \%$ of Santa Catarina menus, the provision of these foods from 2 to 3 times a week ${ }^{10}$; and of Boaventura et al., which found a constant frequency of candies in the menus of day care centers in four municipalities of the Metropolitan Region of São Paulo ${ }^{7}$. Still regarding candies, the law establishes the limit of $10 \%$ of the total energy value, which corresponds to a maximum of two servings a week ${ }^{2}$.

Cured meats and sausages and ultra-processed foods, besides mostly presenting high fat and sodium content, may also contain nitrates - common in cured meats - whose regular or high consumption impairs the quality of a $\operatorname{diet}^{24}$. In the analyzed study, the provision of cured meats was low, considering the findings of Vidal et al. $(2015)^{10}$ : a frequency of $8.68 \%$ was observed in the menus; in turn, they appear at least once a week in $65.6 \%$ of menus, and these results were also found by Longo-Silva et al. (2016), who evaluated the provision of ultra-processed foods to preschool children and identified that, from the sixth month of life, at least $75 \%$ of the sample had previously received one or more ultra-processed food in their feeding ${ }^{25}$.

The meal time compatible with the meal served deserves to be highlighted, given its low frequency of this sample (less than 22\%); this component represents an important aspect of the planning routine of menus; the compatibility between time of provision and type of meal is important to encourage good eating habits ${ }^{2,17}$. This component can be a demotivating factor for food consumption of schoolchildren and may affect their adherence to school meals; however, we have not found researches evaluating the association between consumption and time of the meal. On the other hand, one must not consider as a rule that menus offered in inappropriate times have low quality, which in turn does not diminish the concern with food provision in a time compatible with the type of meal ${ }^{17}$.

The regular provision of important foods for Brazilians, such as rice and beans, were found in the groups Grains and tubers and Legumes, with $86 \%$ and $42.16 \%$, respectively, different from the findings of Vidal et al., who found low frequency of these groups in most menus analyzed (less than once a week $)^{10}$. The combination rice and beans and the appreciation of food culture in school include one of the principles for the promotion of healthy and appropriate eating from a socially and environmentally sustainable food system $^{18}$.

Because these menus are intended to schoolchildren, one would expect a regular offer of dairy, since these foods are sources of vitamins and minerals important for this life stage ${ }^{7,19}$. Milk and derivatives appeared in less than $20 \%$ of the analyzed menus, which confirms the findings of population-based studies ${ }^{20,21}$. Despite the low frequency, most menus analyzed was lunch-type, which justifies the low frequency of dairy, which are commonly present in other meals.

$67 \%$ of the menus analyzed included meat and eggs. The provision of these foods contributes to meeting the nutritional recommendations of micronutrients that are important for this life stage ${ }^{22}$.

The classification of the quality of the menus allowed us to obtain a panorama of the Brazilian school meal (Table 1). This suggests that PNAE law is not being fully met in all Brazilian regions, and also that there is still room for the activity of school meal counselors to be strengthened so as to follow the implementation of PNAE.

The development of actions and strategies of Food and Nutrition Education in school is one of the approaches that may contribute to reverse the situation identified by this study, which shows the low provision of components important for school meals, such as vegetables, fruits, and dairy. The ease of application of IQCAE can promote the local monitoring of PNAE. The main contribution of this study was to show the results of a nationwide qualitative evaluation of menus, which showed the need to increase the provision of vegetables and decrease that of ultra-processed foods; another modification refers to the compatibility between the time the meals is offered and its type to the contribution to the monitoring of the Program.

The main limitations of this study arise from the use of secondary data of municipalities competing for a 2011 prize; this brings the possibility of a bias on the quality of the menus and that the reality may actually be another; another limitation lies in the limited description of the ingredients concerning their degree of processing. 
However, this is the first nationwide study on the quality of school food menus.

\section{Conclusion}

This study recorded the high frequency of grains, tubers, meat, and eggs on school meal menus; on the other hand, it has shown that the provision of cured meats and sausages and ultra-processed foods deserves attention, given the frequency with which they still appear in the menus. The data bring indications for the technical teams of local management, in particular to dietitian, regarding the high use of sweets and the low provision of fruits and vegetables, below the expected limit considering the existence of a specific law to implement the Program. On the other hand, in $20 \%$ of the studied municipalities, the menus meet most of the technical parameters; consequences of these findings could investigate the limiting factors to the proper planning of menus and, especially, the determining factors that contribute to the good performance of the 100 municipalities in which the menus achieved higher scores.

\section{Collaboration}

RGM Camargo contributed with the project design; data analysis and interpretation; writing and critical review of the article; and final approval of the version to be published. SMA Domene contributed with the project design; data analysis and interpretation; critical review of the article; and final approval of the version to be published. SA Caivano contributed with the data analysis interpretation and final approval of the version to be published. 


\section{References}

1. Peixinho AML. A trajetória do Programa Nacional de Alimentação Escolar no período de 2003-2010: relato do gestor nacional. Cien Saude Colet 2013; 18(4):909916.

2. Brasil. Resolução no 26 de 17 de junho de 2013. Dispõe sobre o atendimento da alimentação escolar aos alunos da educação básica no âmbito do Programa Nacional de Alimentação Escolar - PNAE. Brasília: Ministério da Educação; 2013.

3. Fundo Nacional de Desenvolvimento a Educação (FNDE). Dados estatísticos e orçamentos e alunos beneficiados. [internet]. [cited 2019 Maio 1] Available from: http://www.fnde.gov.br/programas/alimentacao -escolar

4. Domene SMA, Belik V. Experiências de programas combinados de alimentação escolar e desenvolvimento local em São Paulo. Agroalimentaria 2012; 18(34):57-72.

5. Teo CRPA, Monteiro CA. Marco legal do Programa Nacional de Alimentação Escolar: uma releitura para alinhar propósitos e práticas na aquisição de alimentos. Rev Nutr 2012; 25(5):657-668.

6. Costa SEP, Mendonça KAN. Avaliação qualitativa de cardápios oferecidos para pré-escolares de creches do Distrito Federal. Universitas: Cien Saude 2012; 10(1):33-40.

7. Boaventura PS, Oliveira AC, Costa JJ, Moreira PVP, Matias ACG, Spinelli MGN, Abreu ES. Avaliação qualitativa de cardápios oferecidos em escolas de educação infantil da grande São Paulo. Demetra 2013; 8(3):397-409.

8. Longo-Silva G, Toloni M, Rodrigues S, Rocha A, Taddei JAAC. Avaliação qualitativa do cardápio e desperdício de alimentos em creches públicas do município de São Paulo. Rev Nutr 2013; 26(2):135-144.

9. Menegazzo M, Fracalossi K, Fernandes AC, Medeiros NI. Avaliação qualitativa das preparações do cardápio de centros de educação infantil. Rev Nutr 2011; 24(2):243-251.

10. Vidal GM, Veiros MB, Souza AA. Cardápios Escolares em SC: avaliação perante a regulamentação do PNAE. Rev Nutr 2015; 28(3):277-287.

11. Machado M, Martins MAA, Andrade GQP, Kraemer FB. A qualidade nutricional e sensorial de preparações proteicas de unidades de alimentação e nutrição escolares: uma avaliação pelo método AQNS. Demetra 2012; 7(3):145-156.

12. Issa RC, Moraes LF, Francisco RRJ, Santos LC, Anjos AFV, Pereira SCL. Alimentação escolar: planejamento, produção, distribuição e adequação. Rev Panam Salud Publica 2014; 35(2):96-103.

13. Gabriel CG, Costa LCF, Calvo MCM, Vasconcelos FAG. Planejamento de cardápios para escolas públicas municipais: Reflexão e ilustração desse processo em duas capitais brasileiras. Rev Nutr 2012; 25(3):363372.

14. Chaves LG, Mendes PNR, Brito RR, Botelho RBA. O programa nacional de alimentação escolar como promotor de hábitos alimentares regionais. Rev Nutr 2009; 22(6):857-866.
15. Camargo RGM. Validação do Indicador de Qualidade para Cardápios da Alimentação Escolar [dissertação]. Santos (SP): Unifesp; 2016.

16. Esfahani A, Wong JM, Truan J, Villa CR, Mirrahimi A, Srichaikul K, Kendall CW. Health effects of mixed fruit and vegetable concentrates: a systematic review of the clinical interventions. J Am Coll Nutr 2011; 30(5):285-94.

17. Kalsbeek A, Scheer FA, Perreau-Lenz S, Fleur SE, Yi C, Fliers E, Buijs RM. Circadian disruption and SCN control of energy metabolism. FEBS Letters 2011; 585(1):1412-1426.

18. Brasil. Ministério da Saúde (MS). Guia Alimentar para a População Brasileira. 2a ed. Brasília: MS; 2014.

19. Rovira RF. La leche y losproductos lácteos: fuentes dietéticas de calcio. Nutr Hosp 2015; 31(Supl. 2):1-9.

20. Instituto Brasileiro de Geografia e Estatística (IBGE). Pesquisa Nacional de Saúde do Escolar 2009: avaliação do estado nutricional dos escolares do $9^{\circ}$ ano do Ensino Fundamental. Rio de Janeiro: IBGE; 2010.

21. Malta DC, Sardinha LMV, Mendes I, Barreto SM, Giatti L, Castro IRR, Moura L, Dias AJR, Crespo C Prevalência de fatores de risco e proteção de doenças crônicas não transmissíveis em adolescentes: resultados da Pesquisa Nacional de Saúde do Escolar (PeNSE), Brasil, 2009. Cien Saude Colet 2010; 15(Supl. 2):3009-3019.

22. Bortolini GA, Vitolo MG. Importância das práticas alimentares no primeiro ano de vida na prevenção da deficiência de ferro. Rev Nutr 2010; 23(6):1051-1062.

23. Brasil. Ministério da Educação. Nota Técnica $n^{o}$ 01/2014. Assunto: Restrição da oferta de doces e preparações doces na alimentação escolar. Brasil: Ministério da Educação; 2014.

24. Domene SMA. Técnica dietética: teoria e aplicações. $2^{\mathrm{a}}$ ed. Rio de Janeiro: Guanabara Koogan; 2018.

25. Longo-Silva G, Silveira JA, Menezes RC, Toloni MH. Age at introduction of ultra-processed food among preschoolchildren attending day-care centers. J Pediatr 2017; 93(1):508-516.

Article submitted 05/05/2019

Approved 29/07/2019

Final version submitted 31/07/2019

Chief Editors: Romeu Gomes, Antônio Augusto Moura da Silva 
